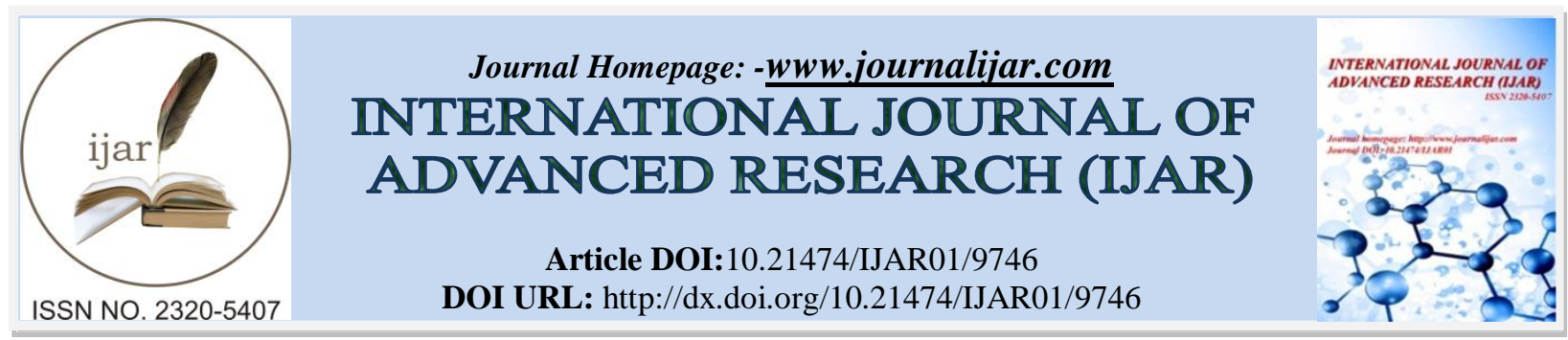

RESEARCH ARTICLE

\title{
FRUSTRATION TOLERANCE BETWEEN SEXES BELONGING TO DIFFERENT COMMUNITY OF HIGHER SECONDARY STUDENTS OF MEGHALAYA.
}

Mrs. Careleen Y. Kharmalki ${ }^{1}$ and Mrs. Sherwin M. Sungoh ${ }^{2}$.

1. Research Scholar, Department of Education, North Eastern Hill University (NEHU), Shilllong, Meghalaya.

2. Professor, Department of Education, North Eastern Hill University (NEHU), Shilllong, Meghalaya.

\section{Manuscript Info}

Manuscript History

Received: 12 July 2019

Final Accepted: 14 August 2019

Published: September 2019

Key words:-

Frustration Tolerance, Adjustment, Sexes and Community .

\begin{abstract}
Frustration is one of the many psychological concepts originated in everyday speech that is all too susceptible to radically different meanings. Even psychologists have used the term in different ways, regardless of their theoretical orientation, fairly well agreed that frustration in some has important implications for personality development and behaviour pathology. The concept of frustration tolerance, however, has an important bearing upon the dynamics of human personality. Frustration tolerance is the ability to withstand obstacles and stressful situations.

To understand the Frustration tolerance of higher secondary students the present study is undertaken. Eight (8) schools comprising of 200 higher Secondary Students were taken as sample for the study. The tool used is a standardised tool known as Frustration Tolerance (FT-RS) developed by Rai, S.N. (2015)

On analysing the data it was found that, the higher secondary students had Low Frustration Tolerance in terms of time taken is $62 \%$ and number of attempts is $85 \%$. Low Frustration Tolerance of Rural students $(95 \%)$ are more than Urban students $(29 \%)$. Low Frustration Tolerance of Tribal students (85\%) are more than Non-tribal students (80.6\%). Low Frustration Tolerance of Male students (89.7\%) are more than the Female students (82.6\%). The study clearly indicates that majority of the Higher Secondary students possess a Low Frustration Tolerance. Also, irrespective of the locale, community or gender maximum percentage of the sample collected the students are having Low Frustration Tolerance. This indicates that the Higher Secondary students will have problem in adjustment and inter personal relationship.
\end{abstract}

Copy Right, IJAR, 2019,. All rights reserved.

\section{Introduction:-}

In psychology, frustration is a common emotional response to opposition, related to anger, annoyance and disappointment. Frustration arises from the perceived resistance to the fulfillment of an individual's will or goal and is likely to increase when a will or goal is denied or blocked. There are multiple ways in which an individual cope with frustration such as passive-aggressive behaviour, anger, or violence, although frustration may

Corresponding Author:-Careleen Y. Kharmalki.

Address:-Research Scholar, Department of Education, North Eastern Hill University (NEHU), Shilllong, Meghalaya. 
also propel positive processes via enhanced effort and strive. This broad range of potential outcomes makes it difficult to identify the original cause(s) of frustration, as the responses may be indirect.

Frustration originates from feelings of uncertainty and insecurity which stems from a sense of inability to fulfil needs. If the needs of an individual are blocked, uneasiness and frustration are more likely to occur. When these needs are constantly ignored or unsatisfied, anger, depression, loss of self-confidence, annoyance, aggression, and sometimes violence are likely to follow.

According to Rosenzweig (1950), frustration occurs whenever the organism meets a more or less insurmountable obstacle or obstruction en route to the satisfaction of any vital need, with the result that behaviour becomes irrational.

The concept of frustration tolerance, however, has an important bearing upon the dynamics of human personality in as much as it indicates the importance of the 'mode of response' to frustrating situation, no matter whether natural or artificially induced. According to English and English (1958) frustration tolerance is the ability to accept frustrating circumstances without disrupting and disordering ones' behaviour.

When an organism is reinforced on some kind of intermittent schedule, a degree of frustration tolerance is built up which enables an individual to continue behaving at a fairly regular rate despite the cessation of reinforcement. When an individual meets with a frustrating situation, he reacts in a specific way, which may be either in the form of a normal way of response or an inadequate mode of response. This difference will depend on the degree of 'frustration tolerance' or how much frustration an individual can withstand (Pareek, 1964). Rosenzweig (1974) has defined frustration tolerance as, an individual's capacity to withstand frustration without failure of psychological adjustment, i.e. without resorting to inadequate modes of response.

Frustration tolerance is the ability to withstand obstacles and stressful situations. Typically conceptualized as an executive functioning impairment, low frustration tolerance is viewed as a problem with self-regulation. Behavioural manifestations include irritability, aggression, liability and refusal to participate. As with other behaviour problems, difficulties with frustration tolerance are often exacerbated by fatigue.

\section{Statement of the problem}

The statement of the study can be stated as: "Frustration Tolerance between sexes of Higher Secondary Students belonging to different community of Meghalaya".

\section{Objectives:-}

1. To study the Frustration tolerance of higher secondary students

2. To find out the Frustration tolerance between rural and urban higher secondary students

3. To find out the Frustration tolerance between communities of higher secondary students

4. To find out the Frustration tolerance between sexes of higher secondary students

\section{Operational Definition of Terms}

1. Frustration Tolerance: Frustration Tolerance refers to the amount of stress one can tolerate before his integrated functioning is seriously impaired (Rai, S.N. 2015)

2. Sexes: They are the two sex namely male and female

3. Community: The community involved in the study belongs to the tribal and non-tribal community

4. Higher Secondary: Students studying in Classes XI and XII

\section{Methodology:-}

Simple statistic was used in the present study which includes percentages.

\section{Research variable}

Frustration Tolerance

\section{Socio-demographic variables}

Locale, community and gender 


\section{Population}

120 Higher Secondary Schools of East Khasi Hills District of Meghalaya

\section{Sample}

200 students from 8 Higher Secondary Schools of East Khasi Hills District of Meghalaya were taken as sample for collection of data. Four schools were taken from rural and four from the urban locale.

\section{Sampling technique}

Stratified Random sampling technique was used for selection of the sample

\section{Description of the tool}

Frustration Tolerance is an experimental material which has four puzzles that a student need to draw within ten minutes and are allowed to proceed only if the puzzle is solved. The first and the third puzzle are solvable, but the second and the fourth are insolvable. Maximum number of attempts to be made by each student is 31 and time is ten minutes.

\section{Scoring}

There is no score allotted for the correct or wrong puzzle solved. But the time and number of attempts are recorded for each student. The number of attempts and time are summed up and Mean time and Mean attempt are calculated.

\section{Analysis and Interpretation}

The data of the present study was analysed using percentage. The analysed data is described briefly and presented in a tabular form.

\section{Objective 1:-To study the Frustration Tolerance of Higher Secondary Students} Tables below shows the overall Frustration Toleranceof Higher Secondary Students

Table 1:-Frustration Tolerance of Higher Secondary Students from Time Taken

\begin{tabular}{|l|l|l|l|l|}
\hline Sl. No. & Classification & $\begin{array}{l}\text { Mean Time Taken (in } \\
\text { mins.) }\end{array}$ & No. of Students & \% \\
\hline 1 & High Frustration Tolerance & $9.0-10$ & 9 & 4.5 \\
\hline 2 & $\begin{array}{l}\text { Above Average Frustration } \\
\text { Tolerance }\end{array}$ & $7.0-8.9$ & 1 & 0.5 \\
\hline 3 & $\begin{array}{l}\text { Average Frustration Tolerance } \\
\text { Below Average Frustration } \\
\text { Tolerance }\end{array}$ & $5.0-6.9$ & 26 & 13.0 \\
\hline 5 & Low Frustration Tolerance & $1.0-2.9$ & 40 & 20.0 \\
\hline Grand Total & & 124 & 62.0 \\
\hline
\end{tabular}

Note: Maximum time $=10$ minutes

Table 2:-Frustration Tolerance of Higher Secondary Students from the No. of Attempts

\begin{tabular}{|l|l|l|l|l|}
\hline Sl. No. & Classification & Mean No. of attempts & No. of Students & $\%$ \\
\hline 1 & High Frustration Tolerance & 25 and above & 2 & 1.0 \\
\hline 2 & Above Average Frustration Tolerance & $19-24$ & 2 & 1.0 \\
\hline 3 & Average Frustration Tolerance & $13-18$ & 4 & 2.0 \\
\hline 4 & Below Average Frustration Tolerance & $7-12$ & 22 & 11.0 \\
\hline 5 & Low Frustration Tolerance & $1-6$ & 170 & 85.0 \\
\hline Grand Total & $\mathbf{2 0 0}$ & \\
\hline
\end{tabular}

\section{Interpretation}

Table 1 above shows that in terms of time taken, 62\% of the Higher Secondary Students have Low Frustration Tolerance, $20 \%$ has Below Average Frustration, 13\% Average, 4.5\% High Frustration Tolerance and 0.5\% only Above Average Frustration Tolerance. From Table 2 regarding the number of attempts, $85 \%$ has Low Frustration Tolerance, $11 \%$ Below Average Frustration Tolerance, 2\% Average Frustration Tolerance and 1\% each has Above Average Frustration Tolerance and High Frustration Tolerance respectively. 
Objective 2: To study the Frustration Tolerance between Rural and Urban Higher Secondary Students

Tables below shows the Frustration Tolerancebetween Rural and Urbanof Higher Secondary Students

Table 3:-Frustration Tolerance between Rural and Urban Higher Secondary Students from Time Taken

\begin{tabular}{|l|l|l|l|l|l|l|}
\hline $\begin{array}{l}\text { Sl. } \\
\text { No }\end{array}$ & Classification & $\begin{array}{l}\text { Mean Time Taken } \\
\text { (in mins.) }\end{array}$ & $\begin{array}{l}\text { No. of Rural } \\
\text { Students }\end{array}$ & $\mathbf{\%}$ & $\begin{array}{l}\text { No. of Urban } \\
\text { Students }\end{array}$ & $\%$ \\
\hline 1 & High Frustration Tolerance & $9.0-10$ & 2 & 2.0 & 7 & 7.0 \\
\hline 2 & $\begin{array}{l}\text { Above Average } \\
\text { Frustration Tolerance }\end{array}$ & $7.0-8.9$ & 1 & 1.0 & Nil & Nil \\
\hline 3 & $\begin{array}{l}\text { Average Frustration } \\
\text { Tolerance }\end{array}$ & $5.0-6.9$ & 1 & 1.0 & 25 & 25.0 \\
\hline 4 & $\begin{array}{l}\text { Below Average Frustration } \\
\text { Tolerance }\end{array}$ & $3.0-4.9$ & 1 & 1.0 & 39 & 39.0 \\
\hline 5 & Low Frustration Tolerance & $1.0-2.9$ & 95 & 95.0 & 29 & 29.0 \\
\hline Grand Total & $\mathbf{1 0 0}$ & & $\mathbf{1 0 0}$ & \\
\hline
\end{tabular}

Note: Maximum time $=10$ minutes

Table 4:-Frustration Tolerance between Rural and Urban Higher Secondary Students from the No. of Attempts

\begin{tabular}{|l|l|l|l|l|l|l|}
\hline $\begin{array}{l}\text { Sl. } \\
\text { No. }\end{array}$ & Classification & $\begin{array}{l}\text { Mean No. of } \\
\text { attempts }\end{array}$ & $\begin{array}{l}\text { No. of Tribal } \\
\text { Students }\end{array}$ & $\mathbf{\%}$ & $\begin{array}{l}\text { No. of Non-Tribal } \\
\text { Students }\end{array}$ & $\%$ \\
\hline 1 & $\begin{array}{l}\text { High Frustration } \\
\text { Tolerance }\end{array}$ & 25 and above & 1 & 1.0 & 1 & 1.0 \\
\hline 2 & $\begin{array}{l}\text { Above Average } \\
\text { Frustration Tolerance }\end{array}$ & $19-24.9$ & 1 & 1.0 & 1 & 1.0 \\
\hline 3 & $\begin{array}{l}\text { Average Frustration } \\
\text { Tolerance Average }\end{array}$ & $13-18.9$ & 2 & 2.0 & 2 & 2.0 \\
\hline 4 & $\begin{array}{l}\text { Below } \\
\text { Frustration Tolerance }\end{array}$ & $1-12.9$ & 1 & 1.0 & 21 & 21.0 \\
\hline 5 & $\begin{array}{l}\text { Low Frustration } \\
\text { Tolerance }\end{array}$ & $1-6.9$ & 95 & 95.0 & 75 & 75.0 \\
\hline
\end{tabular}

\section{Interpretation}

Table 3 above shows that in terms of time taken, 95\% of the Rural and 39\% Urban Higher Secondary Students have Low Frustration Tolerance, 1\% Rural and 39\% Urban has Below Average Frustration Tolerance, 1\% Rural and 25\% Urban Above Average, 1\% Rural Average Frustration Tolerance respectively and 2\% Rural and 7\% Urban has High Frustration Tolerance. From Table 4, regarding the number of attempts, 95\% Rural and 21\% Urban has Low Frustration Tolerance, 2\% Rural and Urban has Below Average Frustration Tolerance and, 1\% Rural and Urban has Above Average and High Frustration Tolerance respectively.

Objective 3: To find out the Frustration Tolerance between communities of Higher Secondary Students Tables below shows the Frustration TolerancebetweenTribal and Non-TribalHigher Secondary Students

Table 5:-Frustration Tolerance of Tribal and Non-tribal Higher Secondary Students from Time Taken

\begin{tabular}{|l|l|l|l|l|l|l|}
\hline $\begin{array}{l}\text { Sl. } \\
\text { No }\end{array}$ & Classification & $\begin{array}{l}\text { Mean Time Taken } \\
\text { (in mins.) }\end{array}$ & $\begin{array}{l}\text { No. of Tribal } \\
\text { Students }\end{array}$ & $\mathbf{\%}$ & $\begin{array}{l}\text { No. of Non-Tribal } \\
\text { Students }\end{array}$ & \% \\
\hline 1 & High Frustration Tolerance & $9.0-10$ & 6 & 3.6 & 3 & 25.8 \\
\hline 2 & $\begin{array}{l}\text { Above Average Frustration } \\
\text { Tolerance }\end{array}$ & $7.0-8.9$ & 1 & 0.6 & Nil & Nil \\
\hline 3 & $\begin{array}{l}\text { Average Frustration } \\
\text { Tolerance }\end{array}$ & $5.0-6.9$ & 18 & 10.7 & 8 & 3.4 \\
\hline 4 & $\begin{array}{l}\text { Below Average Frustration } \\
\text { Tolerance }\end{array}$ & $3.0-4.9$ & 27 & 16.0 & 13 & 41.9 \\
\hline 5 & Low Frustration Tolerance & $1.0-2.9$ & 117 & 69.2 & 7 & 22.6 \\
\hline Grand Total & $\mathbf{1 6 9}$ & & $\mathbf{3 1}$ & \\
\hline
\end{tabular}


Note: Maximum time $=10$ minutes

Table 6:-Frustration Tolerance of Tribal and Non-tribal Higher Secondary Students from the No. of Attempts

\begin{tabular}{|l|l|l|l|l|l|l|}
\hline $\begin{array}{l}\text { SI. } \\
\text { No }\end{array}$ & Classification & $\begin{array}{l}\text { Mean No. of } \\
\text { attempts }\end{array}$ & $\begin{array}{l}\text { No. of Tribal } \\
\text { Students }\end{array}$ & $\mathbf{\%}$ & $\begin{array}{l}\text { No. of Non-Tribal } \\
\text { Students }\end{array}$ & $\%$ \\
\hline 1 & $\begin{array}{l}\text { High Frustration } \\
\text { Tolerance }\end{array}$ & 25 and above & 1 & 0.6 & 1 & 3.2 \\
\hline 2 & $\begin{array}{l}\text { Above Average } \\
\text { Frustration Tolerance }\end{array}$ & $19-24.9$ & 1 & 0.6 & 1 & 3.2 \\
\hline 3 & $\begin{array}{l}\text { Average Frustration } \\
\text { Tolerance }\end{array}$ & $13-18.9$ & 4 & 2.4 & Nil & Nil \\
\hline 4 & $\begin{array}{l}\text { Below Average } \\
\text { Frustration Tolerance }\end{array}$ & $7-12.9$ & 18 & 10.7 & 4 & 12.9 \\
\hline 5 & $\begin{array}{l}\text { Low Frustration } \\
\text { Tolerance 1-6.9 }\end{array}$ & 145 & 85.8 & 25 & 80.6 \\
\hline Grand Total & $\mathbf{1 6 9}$ & & $\mathbf{3 1}$ & \\
\hline
\end{tabular}

\section{Interpretation}

Table 5 above shows that in terms of time taken, 3.6\% Tribal and 25.8\% Non-tribal of the Higher Secondary Students have Low Frustration Tolerance, 10.6\% Tribal students has Below Average Frustration, $10.7 \%$ Tribal and 3.4\% Non-tribal students has Average, 16\% Tribal and 41.9\% Non-tribal has Above Average and, $69.2 \%$ Tribal and 22.6\% Non-tribal students has High Frustration Tolerance. From Table 6 above regarding the number of attempts, 85.8\% Tribal and $80.6 \%$ Non-tribal has Low Frustration Tolerance, 10.7\% Tribal and 12.9\% Non-tribal Below Average Frustration Tolerance, 2.4\% Tribal has Average Frustration Tolerance, 0.6\% Tribal and 3.2\% Non-tribal has Above Average and High Frustration Tolerance respectively.

Objective 4: To find out the Frustration Tolerance between sexes of Higher Secondary Students

Tables below shows the overall Male and FemaleFrustrationTolerance of Higher Secondary Students

Table 7:-Frustration Tolerance of Male and Female Higher Secondary Students from Time Taken

\begin{tabular}{|l|l|l|l|l|l|l|}
\hline $\begin{array}{l}\text { Sl. } \\
\text { No }\end{array}$ & Classification & $\begin{array}{l}\text { Mean Time Taken } \\
\text { (in mins.) }\end{array}$ & $\begin{array}{l}\text { No. of Male } \\
\text { Students }\end{array}$ & $\mathbf{\%}$ & $\begin{array}{l}\text { No. of Female } \\
\text { Students }\end{array}$ & \% \\
\hline 1 & High Frustration Tolerance & $9.0-10$ & Nil & Nil & 7 & 5.3 \\
\hline 2 & $\begin{array}{l}\text { Above Average Frustration } \\
\text { Tolerance }\end{array}$ & $7.0-8.9$ & Nil & Nil & 1 & 0.8 \\
\hline 3 & $\begin{array}{l}\text { Average Frustration } \\
\text { Tolerance }\end{array}$ & $5.0-6.9$ & 2 & 2.9 & 26 & 19.7 \\
\hline 4 & $\begin{array}{l}\text { Below Average Frustration } \\
\text { Tolerance }\end{array}$ & $3.0-4.9$ & 10 & 14.7 & 30 & 22.7 \\
\hline 5 & Low Frustration Tolerance & $1.0-2.9$ & 56 & 82.4 & 68 & 51.5 \\
\hline Grand Total & $\mathbf{6 8}$ & & $\mathbf{1 3 2}$ & \\
\hline
\end{tabular}

Note: Maximum time $=10$ minutes

Table 8:-Frustration Tolerance of Male and Female Higher Secondary Students from the No. of Attempts

\begin{tabular}{|l|l|l|l|l|l|l|}
\hline $\begin{array}{l}\text { Sl. } \\
\text { No }\end{array}$ & Classification & $\begin{array}{l}\text { Mean No. of } \\
\text { attempts }\end{array}$ & $\begin{array}{l}\text { No. of Male } \\
\text { Students }\end{array}$ & $\mathbf{\%}$ & $\begin{array}{l}\text { No. of Female } \\
\text { Students }\end{array}$ & $\%$ \\
\hline 1 & High Frustration Tolerance & 25 and above & 1 & 1.5 & 1 & 0.8 \\
\hline 2 & $\begin{array}{l}\text { Above Average Frustration } \\
\text { Tolerance }\end{array}$ & $19-24.9$ & 1 & 1.5 & 1 & 0.8 \\
\hline 3 & $\begin{array}{l}\text { Average Frustration } \\
\text { Tolerance }\end{array}$ & $13-18.9$ & Nil & Nil & 4 & 3.0 \\
\hline 4 & $\begin{array}{l}\text { Below Average Frustration } \\
\text { Tolerance }\end{array}$ & $7-12.9$ & 5 & 7.4 & 17 & 12.9 \\
\hline 5 & Low Frustration Tolerance & $1-6.9$ & 61 & 89.7 & 109 & 82.6 \\
\hline Grand Total & $\mathbf{6 8}$ & & $\mathbf{1 3 2}$ & \\
\hline
\end{tabular}




\section{Interpretation}

Table 7 above shows that in terms of time taken, $82.4 \%$ Male and 51.5\% Female Higher Secondary Students have Low Frustration Tolerance, 14.7\% Male and 22.7\% Female students has Below Average Frustration, 2.9\% Male and 19.7\% Female students has Average, 0.8\% and 5.3\% Female has Above Average and High Frustration Tolerance respectively. From Table 8 above regarding the number of attempts, 82.4\% Male and 51.5\% Female students has Low Frustration Tolerance, 7.4\% Male and 12.9\% Female has Below Average Frustration Tolerance, 3\% Female students has Average Frustration Tolerance, 1.5\% Male and 0.8\% Female has Above Average and High Frustration Tolerance respectively.

\section{Discussion:-}

The findings of the present study clearly indicate that Frustration Tolerance of Higher Secondary Students of East Khasi Hills district were found to be Low. Since the tool involves time and number of attempts, the students were tested on both the aspect. Majority of the students has Low Frustration Tolerance. It was found that Low Frustration Tolerance of Rural students are more than Urban students, Tribal students are more than Non-tribal students and Male are more than Female students respectively. This clearly indicates that the Higher Secondary students cannot withstand obstacles and stressful siyuations. They have the inability to tolerate frustration which can lead to many maladjustment and problems in inter-personal relationship.

\section{Recommendations}

1. Interventions can be carried out to improve the students' Frustration Tolerance level.

2. The study of Frustration Tolerance can also be carried out for secondary as well as higher level of studies

3. Frustration Tolerance can be studied with other variables which can enhance the level of Frustration Tolerance in an individual

4. Similar studies can be carried out at a larger scale

\section{Acknowledgement:-}

First and foremost my heartfelt gratitude goes to Almighty God who gave me strength and patience to write this paper and for his unfailing love, grace and glory at all times.

I thank my husband, children and all well wishers for the unconditional support and love for me at all times and place.

My gratitude to my co author Prof. S. M. Sungoh for the guidance and support she gave whenever I require.

Last but not the least I convey my thankfulness to the Principals, Teachers of schools for granting permission to conduct the study in their respective schools without forgetting the students for their cooperation and participation without which the study would be meaningless.

\section{References:-}

1. Bouman D.E. (2011) Frustration Tolerance. In: Kreutzer J.S., DeLuca J., Caplan B. (eds) Encyclopedia of ClinicalNeuropsychology. Springer, New York, NY. Retrieved from DOI: https://doi.org/10.1007/978-0387-79948-3_2139 on 28.8.19

2. Fozdar, S. (2015). A study of values locus of control and frustration tolerance in working non working married and unmarried women. Retrieved from http://hdl.handle.net/10603/48243 retrieved on 28.8.19

3. Frustration. In Wikipedia, The Free Encyclopedia. Retrieved 10:02, September 24, 2019, from https://en.wikipedia.org/w/index.php?title=Frustration\&oldid=914857912

4. Pal, A. (2014). Religiosity and gender as determinants of frustration tolerance and altruism different religious groups. Retrieved from http://shodhganga.inflibnet.ac.in:8080/jspui/bitstream/10603/45717/11/11_chapter\%201.pdf on 28.8.19

5. Rai, S.N. (2015). Instructional Manual for Frustration Tolerance. National Psychological Corporation, Agra 